\title{
Effect of slow release fertilizers application on growth and chemical composition of some indoor plants
}

\author{
A. A. M. El-Naggar. ${ }^{1}$, A. H. El-Naggar ${ }^{2}$ and N. M. Ismaiel ${ }^{1}$
}

\begin{abstract}
The present study was carried out during two successive seasons (2008 and 2009) at the Nursery of the Alexandria University, Somoha, Alexandria, Egypt to determined the optimum rate of application of two types of slow release fertilizers [Hydro complex (HC) and PG-Mix (PG)] on growth and chemical composition of some indoor plants (Dracaena marginata and Beaucarnea recuvata) growing in pot experiments.

With respect to the Dracaena marginata experiment, it was found that applying $15 \mathrm{~g} /$ plant of $\mathrm{HC}$ at four-month intervals resulted in the highest significant values of plant height, leaf number/plant, leaf length and width, stem diameter, root volume and root dry weight. Moreover, applying the above mentioned treatment gave the highest significant values of leaf NPK contents, leaf total chlorophyll contents and total carbohydrates.
\end{abstract}

Whereas, fertilizing the plants with PG at rate of application of $15 \mathrm{~g} /$ plant at four-month intervals resulted in the highest significant values of fresh and dry weights of leaves. On the other hand, the results indicated that there were no significant differences detected due to applying 15 g or $10 \mathrm{~g} /$ plant at four-month intervals of $\mathrm{HC}$ on leaf number/plant, leaf length and width, stem diameter, root dry weight, leaf phosphorus and total carbohydrates contents.

Regarding the Beaucarnea recuvata experiment, the results indicated that fertilizing the plants with $\mathrm{HC}$ at rate of application of $15 \mathrm{~g} /$ plant at four-month intervals resulted in the highest significant values of leaf number/plant, leaf length and width, fresh and dry weights of leaves, stem length and stem diameter, root volume, as well as gave the highest significant values of leaf NPK contents and total carbohydrates. Whereas, fertilizing the plants with PG at rate of application of $15 \mathrm{~g} /$ plant at fourmonth intervals resulted in the highest significant values of total leaf chlorophyll contents. On the other hand, it was found that there were no significant differences detected due to applying either 15 or $10 \mathrm{~g}$ of PG on leaf number/plant, leaf length, stem length and diameter, root volume and leaf nitrogen and potassium contents. Whereas, applying with $10 \mathrm{~g} /$ plant of PG at four-month intervals resulted in the highest significant values of leaf total chlorophyll contents.

The study recommends applying the slow release fertilizer Hydro complex at rate of application of $15 \mathrm{~g} / \mathrm{plant}$ at four-month intervals to get the most quality of the characters study of Dracaena marginata and Beaucarnea recuvata plants grown in pots.

Key word: indoor plants, slow release fertilizers, mineral fertilizer, Dracaena marginata, Beaucarnea recuvata

\section{INTRODUCTION}

Slow-release fertilizers are now considered a valuable tool for fertilizing the container nursery crops and environmental friendly practice. Thus providing a more efficient and localized supply of nutrients than overhead fertigation. Researches indicate that as much as $70 \%$ of the water and nutrients applied to a container crop by overhead liquid feeding can be lost by runoff and leaching (Xiang YAN et al ., 2008). The extent of these losses is a function of the container spacing, canopy cover (foliage density) and the volume of solution applied. A significant amount of water and nutrients typically falls in between containers even when they are closely spaced. In addition, as the crop matures it closes its canopy and behaves like an umbrella, preventing the entry of water and nutrients into the container. As a consequence, larger volumes of solution need to be applied which further increases water and nutrient losses (Chien et al., 2010).

The use of slow release fertilizers are excellent alternative to soluble fertilizers (Laiche, 1991). These fertilizers offers several advantages i.e., reduction of nutrient losses from the container by leaching and runoff; avoidance of high initial salt levels in the growing media; availability of nutrients during the entire growing season; containment of all the fertilizer in the container; less frequent application is required. Furthermore, fertilizer burn is not a problem with SLRs even at high rates of application (Yuan-liang et al., 2009).

Slow-release fertilizer (SLF) is used to define either the organic fertilizer materials like animal by-products i.e., hoof, manures, horn or the chemical fertilizers of low solubility like Urea Formaldehyde (Ureaform or Nitroform), Isobutylidene-diurea (IBDU)or Hdrocomplex. Slow release fertilizers are generally categorized into one of several groups based on the process by which the nutrients are released. These

\footnotetext{
${ }^{1}$ Ornamental Plants Research Branch, Horticultural Research Institute Antoniades Gardens, Alexandria, Egypt.

${ }^{2}$ Floriculture, Ornamental Horticulture and landscape Gardening Dept., Faculty of Agric., (EL-Shatby), Alexandria Univ. Egypt.

Received May 2, 2010, Accepted May31, 2010
} 
fertilizers could be pellitized, chemically altered, coated or encapsulated in membranes (Blaylock et al., 2005).

In case of the two chosen slow release fertilizers used in the present study, they were consisted of relatively insoluble nutrients in palletized form (Laiche, 1991).The main factors affecting nutrients release from the studied SLRs are the particle size. As the pellet size increased, the time takes for the fertilizer to breakdown by microbial activity is also increased (Hartrath, 1986).

The slow release fertilizers investigated in the present study were: Hydro complex and PG-Mix. They are commercially used for container nursery plants and are appropriate for use on tree seedlings, turf, ornamental and flower borders with a duration of nutrients release of 3-4 months (Kirk,1993). Gardeners need to be aware of exactly the recommended rate of application for specific plant species, especially the greenhouse plants.

Several researches were carried out on evaluating different types of slow release fertilizers on ornamental plants i.e., Jarrell et al., (1983) on container-grown Ligustrum texanum Thunb, Conover et al ., (1985) on Ficus benjamina, Ticknor et al ., (1987) on Rhododendrons, Worrall et al., (1987) on an Australian native and exotic woody ornamentals, Catanzaro et al ., (1998) on potted chrysanthemum, Lamont et al ., (1988) on kentia palm, Hector et al ., (2003) on willow and Oliet et al., (2004), on Pinus halepensis seedlings.

The two indoor plants used in the present investigation were, Dracaena marginata and Beaucarnea recuvata. They belong to the family Ruscaceae.Dracaena marginata (Madagascar dragon tree or red edged dracaena) is native to Madagascar. It is a slow growing shrub or small tree. It is a popular houseplant that needs little attention and minimal care so it is very popular in offices where the constant heat and light suits their growing requirements (Huxley,1992). Beaucarnea recuvata often called the ponytail palm even though it is not a true palm. It is native to Mexico. It needs full sun to light shade. Plants are very slow growing and it can be used as a tube indoor plant or as a specimen (Irish, 2000).

The main purpose of the present investigation was to study the optimum rate of application of the chosen SLFs (Hydro complex and PG-Mix) comparing with the control (unfertilized plants) on growth and chemical composition of two indoor plants (Dracaena marginata and Beaucarnea recuvata).

\section{MATERIALS AND METHODS}

The present work was carried out during two successive seasons (2008 and 2009) at the Nursery of the Alexandria University, Somoha, Alexandria, Egypt.
Uniformed plants of one year old with a height of $40 \mathrm{~cm}$ of Dracaena marginata and uniformed Beaucarnea recuvata plants, with an approximately 10 leaf each and a stem length of about $3 \mathrm{~cm}$ above the soil surface, were used in pot experiments. Two types of granular slow release fertilizers (fine and coarse) were investigated for their effects on the growth of the above mentioned plant species in comparison with the control (unfertilized plants) in two separate experiments.

\section{Experimental treatments:}

The slow release fertilizers used in the present investigation were PG-Mix (PG) with NPK ratio of (12: 11:18) and Hydro complex (HC) with NPK ratio of (14: 16:18), supplied by Hydro Agri Trade Egypt Company (HATE), were added at the start of the experiment and repeated after 4 months for 2 times at rates of application of 5, 10 and/or $15 \mathrm{~g} /$ pot. The plants were fertilized two times on $15^{\text {th }}$ and $17^{\text {th }}$ Feb and $15^{\text {th }}$ and $17^{\text {th }}$ June for both plant species in the two seasons, respectively.

\section{Experimental design:}

The experiments were designed to provide a randomized complete block with three replicated. Each experimental unites consisted of 6 plants as a plot. Commercial insect and disease agricultural practices were applied as needed.

\section{Soil analysis:}

The mechanical analysis of the used soil revealed that it was containing $16.24 \% 26.40 \%$ and $57.36 \%$ of clay, silt and sand, respectively. The chemical analysis cleared that, it was containing $0.19,0.06$ and $0.21 \%$ of $\mathrm{N}, \mathrm{P}_{2} \mathrm{O}_{5}$ and $\mathrm{K}_{2} \mathrm{O}$, respectively. The electric conductivity (EC) was $2.14\left(\mathrm{dsm}^{-1}\right)$ with $\mathrm{pH}$ of 7.54.

\section{Growth characteristics:}

The data recorded for both of Dracaena marginata and Beaucarnea recuvata plants at the end of the experiments on $15^{\text {th }}$ Oct and $17^{\text {th }}$ Oct for both seasons, respectively. in the two successive seasons included: plant height, leaf number/plant, leaf length and width, fresh and dry weights of leaves, stem length, stem diameter, root volume as well as total leaf chlorophyll contents $(\mathrm{mg} / 100 \mathrm{~g}$ leaf fresh weight). Stem fresh and dry weights and root dry weight were also recorded for Beaucarnea recuvata plants.

\section{Chemical composition:}

The chemical analysis of leaves i.e. leaf Nitrogen (\%), Phosphorus (\%), Potassium (\%) and leaf total carbohydrates contents $(\%)$ were also determined for both of the studied species. The nitrogen content and phosphorus percentage of the dried leaves were determined according to methods described by 
Chapman and Pratt (1961) and Bringham (1982). The potassium percentage was determined by using Flame Photometer according to Brown and Lilleland (1946) and Chapman and Pratt (1961). The total carbohydrate content in dried leaf samples was determined according to Herbert et al., (1971). Total chlorophyll contents in the leaves were carried out according to the methods described by Greig et al., (1968).

\section{Statistical analysis:}

Data were statistically analyzed according to the methods described by Snedecor and Cochran (1981).

\section{RESULTS AND DISCUSSION}

\section{A - Dracaena marginata:}

\section{I- Vegetative growth parameters:}

\section{1- Plant height (cm):}

Applying all fertilizer treatments resulted in significant increase in plant height compared with the control (Table 1).Fertilizing dracaena plants with $15 \mathrm{~g}$ $\mathrm{HC}$ gave the highest significant values in both seasons as compared with the other fertilizer. However, no significant differences in plant height were observed due to applying the three different rates of application of HC.

\section{2- Leaf number/plant:}

The data in Table (1) show that all fertilizer treatments significantly increased this parameter as compared with the control except for in case of applying $5 \mathrm{~g} \mathrm{PG}$ in first season. The highest leaf number/plant was found with plants received the highest rate of application of HC (15 g) in both seasons. Also, it can be noticed that applying either the medium or highest rate of application of $\mathrm{HC}$ resulted in significant similar effects between them on this parameter.

\section{3- Leaf length and width $(\mathrm{cm})$ :}

The results listed in Table (1) revealed that all fertilizer treatments significantly affected leaf length and width in both cultivations except for in case of fertilizing the plants with $5 \mathrm{~g}$ PG in the first season.

With respect to leaf length, the plants received the highest rate of application of $\mathrm{HC}(15 \mathrm{~g})$ gave the highest leaf length in both seasons. However, no significant differences in leaf length were detected due to applying the medium or the highest rate of application of HC.

Regarding the leaf width parameter, it was found fertilizing the plants with the highest rate of application of $\mathrm{HC}$ resulted in the highest significant values of leaf width. It can be noticed that fertilizing the plants with any level used of $\mathrm{HC}$ had similar effects on leaf width.

\section{4- Stem diameter (cm):}

Results illustrated in Table (1) show that applying all fertilizer treatments resulted in significant increases in stem diameter compared with the control. The highest stem diameter values were recorded in plants received the highest level of the slow release fertilizers (15 g). However, no significant differences were detected due to applying the highest or the medium rate of application of $\mathrm{HC}$.

\section{5- Fresh and dry weights of leaves (g):}

Data in Table (2) demonstrate the significant effects of the fertilizer treatments on fresh and dry weights of leaves except for in case of fertilizing the plants with the lowest rate of application of PG (5 g) where no significant differences were detected compared with the control in leaf fresh weight parameter for both seasons. The results showed that the plants received the highest rate of application of the both fertilizers $(15 \mathrm{~g})$ had the highest recorded values of these parameters in both seasons. Also, the results revealed that no significant differences were detected in leaf fresh and dry weight recorded values due to applying the highest rate of application of any of the slow release fertilizers used (HC or PG).

\section{II- Root parameters: \\ 1- Root volume $\left(\mathrm{cm}^{3}\right)$ :}

Data illustrated in Table (2) revealed that significant effects on root volume as a result of applying all fertilizer treatments. The highest recorded values of root volume were recorded with plants received the highest rate of $\mathrm{HC}(15 \mathrm{~g})$ followed by applying $15 \mathrm{~g}$ PG in both seasons. Also, it was found that applying the lowest or medium rate of application of $\mathrm{HC}$ had significant similar effect. Moreover, the results indicated that no significant differences were detected due to receiving the plants the highest or medium rate of application of PG fertilizer.

\section{2- Root dry weight (g):}

The results shown in Table (2) demonstrate that root dry weight was significantly increased with all fertilizer treatments in both seasons. The highest recorded root weight values were obtained in plants received the highest rate of application of $\mathrm{HC}(15 \mathrm{~g})$ followed by applying the medium rate of application of $\mathrm{HC}(10 \mathrm{~g})$ in both seasons.

\section{III- Chemical composition of leaves:}

\section{1-Total chlorophyll contents:}

The data shown in Table (3), revealed that the total chlorophyll contents was significantly increased with all fertilizer treatments as compared the control in both seasons. The highest significant values were recorded in 
Table 1. Effect of different rates of application of two types of slow release fertilizers on plant height $(\mathrm{cm})$, leaf number per plant, leaf length $(\mathrm{cm})$, leaf width $(\mathrm{cm})$ and stem diameter $(\mathrm{cm})$ of Dracaena marginata plants during 2008 and 2009 seasons

\begin{tabular}{|c|c|c|c|c|c|}
\hline Treatments & $\begin{array}{l}\text { Plant height } \\
\text { (cm) }\end{array}$ & $\begin{array}{c}\text { Leaf number } \\
\text { / plant }\end{array}$ & $\begin{array}{c}\text { Leaf } \\
\text { length } \\
(\mathbf{c m})\end{array}$ & $\begin{array}{l}\text { Leaf width } \\
\quad(\mathrm{cm})\end{array}$ & $\begin{array}{c}\text { Stem Diameter } \\
(\mathbf{c m})\end{array}$ \\
\hline & \multicolumn{5}{|c|}{$1^{\text {st }} \operatorname{season}(2008)$} \\
\hline Control & 66.33 & 29.00 & 32.90 & 1.96 & 0.85 \\
\hline PG-Mix $5 \mathrm{~g}$ & 78.00 & 36.33 & 36.96 & 2.46 & 1.10 \\
\hline $\begin{array}{ll}\text { PG-Mix } 10 \mathrm{~g} \\
\end{array}$ & 80.33 & 38.33 & 39.60 & 2.53 & 1.21 \\
\hline PG-Mix $15 \mathrm{~g}$ & 86.00 & 38.66 & 41.13 & 2.73 & 1.43 \\
\hline Hydro complex $5 \mathrm{~g}$ & 82.66 & 37.66 & 41.23 & 2.60 & 1.26 \\
\hline Hydro complex $10 \mathrm{~g}$ & 83.66 & 41.00 & 42.43 & 2.66 & 1.30 \\
\hline Hydro complex $15 \mathrm{~g}$ & 93.00 & 47.33 & 41.33 & 2.76 & 1.43 \\
\hline L.S.D.(0.05) & 13.13 & 7.69 & 4.07 & 0.36 & 0.17 \\
\hline Treatments & \multicolumn{5}{|c|}{$2^{\frac{\text { nd }}{2}}$ season $(2009)$} \\
\hline Control & 65.33 & 27.33 & 31.60 & 2.00 & 0.86 \\
\hline PG-Mix $5 \mathrm{~g}$ & 77.66 & 35.33 & 34.90 & 2.50 & 1.20 \\
\hline $\begin{array}{ll}\text { PG-Mix } 10 \mathrm{~g} \\
\end{array}$ & 81.00 & 36.33 & 38.13 & 2.56 & 1.25 \\
\hline PG-Mix $15 \mathrm{~g}$ & 84.00 & 37.33 & 40.80 & 2.66 & 1.41 \\
\hline Hydro complex $5 \mathrm{~g}$ & 81.66 & 36.66 & 38.66 & 2.70 & 1.25 \\
\hline Hydro complex $10 \mathrm{~g}$ & 85.66 & 44.00 & 42.96 & 2.73 & 1.35 \\
\hline Hydro complex $15 \mathrm{~g}$ & 91.00 & 45.66 & 46.13 & 2.76 & 1.41 \\
\hline L.S.D.(0.05) & 9.34 & 4.74 & 3.15 & 0.32 & 0.09 \\
\hline
\end{tabular}

L.S.D. ${ }_{(0.05)}=$ Least significant difference at 0.05 level of probability.

plants received the highest rate of the slow release fertilizer $\mathrm{HC}(15 \mathrm{~g})$ in both seasons.

2- N, $P$ and $K$ contents of leaves:

Results of the dracaena leaves chemical analysis for their N, P, K contents are listed in Table (3). Statistical analysis of these results revealed that all fertilizer treatments significantly increased leaf N, P, K contents of dracaena leaves in both seasons except for in case of applying $5 \mathrm{~g}$ of PG fertilizer which did not significantly affected leaf $\mathrm{K}$ content in both seasons.

Applying $\mathrm{HC}$ at the highest rate $(15 \mathrm{~g})$ resulted in the highest $\mathrm{N}, \mathrm{P}$, and $\mathrm{K}$ contents of dracaena leaves for both seasons. Also, the results revealed that there were no significant differences due to receiving the plants either the highest or the medium rate of application of $\mathrm{HC}$ with respect to leaf phosphorus content.

\section{3- Total carbohydrates of leaves:}

The data presented in Table (3) demonstrate that all fertilizer treatments had significant effects on leaf total carbohydrates as compared with the control except for in case of fertilizing the plants with the lowest rate of application of PG $(5 \mathrm{~g})$. The highest significant values were recorded in plants received the highest rate of application of HC $(15 \mathrm{~g})$ in both seasons. Also, it can be noticed that no significant differences were detected due to applying either the highest or the medium rate of application of $\mathrm{HC}$ fertilizer.

\section{B- Beaucarnea recuvata:}

\section{I- Vegetative growth parameters:}

The results revealed that all fertilizer treatments significantly affected the studied vegetative growth parameters compared with the control for both seasons. 
Table 2. Effect of different rates of application of two types of slow release fertilizers on leaf fresh weight (g), leaf dry weight ( $\mathrm{g}$ ), root volume $\left(\mathrm{cm}^{3}\right)$ and root dry weight (g) of Dracaena marginata plants during 2008 and 2009 seasons

\begin{tabular}{|c|c|c|c|c|}
\hline \multirow[t]{2}{*}{ Treatments } & $\begin{array}{l}\text { Leaf fresh } \\
\text { weight (g) }\end{array}$ & $\begin{array}{l}\text { Leaf dry } \\
\text { Weight (g) }\end{array}$ & $\begin{array}{c}\text { Root } \\
\text { volume }\left(\mathrm{cm}^{3}\right)\end{array}$ & $\begin{array}{c}\text { Root } \\
\text { dry weight } \\
\text { (g) }\end{array}$ \\
\hline & \multicolumn{4}{|c|}{$1^{\text {st }} \operatorname{season}(2008)$} \\
\hline Control & 136.33 & 20.70 & 101.66 & 19.86 \\
\hline PG-Mix $5 \mathrm{~g}$ & 164.60 & 23.80 & 135.00 & 24.86 \\
\hline $\begin{array}{ll}\text { PG-Mix } 10 \mathrm{~g} \\
\end{array}$ & 182.81 & 27.96 & 171.66 & 32.00 \\
\hline PG-Mix $15 \mathrm{~g}$ & 270.60 & 56.56 & 175.00 & 37.06 \\
\hline Hydro complex $5 \mathrm{~g}$ & 194.14 & 32.63 & 173.33 & 31.13 \\
\hline Hydro complex $10 \mathrm{~g}$ & 202.94 & 35.50 & 170.00 & 36.96 \\
\hline Hydro complex $15 \mathrm{~g}$ & 250.01 & 49.16 & 206.66 & 51.56 \\
\hline L.S.D.(0.05) & 41.23 & 2.74 & 23.57 & 2.99 \\
\hline Treatments & \multicolumn{4}{|c|}{$2^{\text {nd }} \operatorname{season}(2009)$} \\
\hline Control & 140.00 & 22.53 & 93.33 & 21.40 \\
\hline PG-Mix $5 \mathrm{~g}$ & 168.06 & 25.50 & 131.66 & 26.33 \\
\hline $\begin{array}{ll}\text { PG-Mix } 10 \mathrm{~g} \\
\end{array}$ & 181.17 & 28.60 & 175.00 & 35.56 \\
\hline PG-Mix $15 \mathrm{~g}$ & 247.81 & 59.26 & 178.33 & 39.66 \\
\hline Hydro complex $5 \mathrm{~g}$ & 198.51 & 35.10 & 168.33 & 34.76 \\
\hline Hydro complex $10 \mathrm{~g}$ & 201.65 & 38.46 & 173.33 & 39.33 \\
\hline Hydro complex $15 \mathrm{~g}$ & 256.15 & 53.03 & 215.00 & 53.30 \\
\hline L.S.D. $_{(0.05)}$ & 41.41 & 3.05 & 18.35 & 2.98 \\
\hline
\end{tabular}

L.S.D. ${ }_{(0.05)}=$ Least significant difference at 0.05 level of probability.

\section{1-Leaf number/plant:}

It can be observed from the data in Table (4) that the highest values of leaf number/plant values were recorded in plants received the highest rate of application of the HC (10 and/or15 g) in both seasons. Also, it can be noticed that fertilizing the plants either with the highest or the medium rate of application of $\mathrm{HC}$ had significant similar effects on this parameter.

\section{2- Leaf length and width (cm):}

The results listed in table (4) revealed that all fertilizer treatments significantly affected leaf length and width as compared with the control. Fertilizing the plants with the highest level of $\mathrm{HC}(15 \mathrm{~g})$ resulted in the highest significant values of theses parameters. However, the results indicated that there were no significant differences in recorded leaf length values due to applying either $15 \mathrm{~g}$ or $10 \mathrm{~g}$ of PG. Also, it can be observed that applying any level of PG had significant similar effects on leaf width.

\section{3- Fresh and dry weights of leaves (g):}

Data presented in Table (4) reveal significant effects of fertilizer treatments on leaf fresh and dry weights compared with the control. Fertilizing the plants with 15 g HC gave the highest values in both seasons. Also, no significant differences in leaf fresh weight values were detected due to applying the lowest or the medium rate of application of HC fertilizer. Also, it was found that applying either the highest or the medium rate of application of PG fertilizer had significant similar effects on leaf fresh weight. 
Table 3. Effect of different rates of application of two types of slow release fertilizers on total chlorophyll contents (mg/100 $\mathrm{g}$ fresh weight), leaf nitrogen $(\%)$, phosphorus $(\%)$, potassium (\%) contents and total carbohydrate $(\%)$ of Dracaena marginata plants during 2008 and 2009 seasons

\begin{tabular}{|c|c|c|c|c|c|}
\hline Treatments & $\begin{array}{c}\text { Total } \\
\text { chlorophyll } \\
\text { contents } \\
\text { mg/100 g leaf } \\
\text { fresh weight }\end{array}$ & $\mathbf{N}(\%)$ & $\mathbf{P}(\%)$ & $\mathbf{K}(\%)$ & $\begin{array}{c}\text { Total } \\
\text { carbohydrates } \\
(\%)\end{array}$ \\
\hline & & \multicolumn{4}{|c|}{$1^{\text {st }}$ season $(2008)$} \\
\hline Control & 91.80 & 0.86 & 0.26 & 1.82 & 33.15 \\
\hline PG-Mix 5 g & 141.60 & 1.02 & 0.38 & 1.97 & 37.08 \\
\hline PG-Mix $10 \mathrm{~g}$ & 144.43 & 1.39 & 0.46 & 2.15 & 44.73 \\
\hline PG-Mix $15 \mathrm{~g}$ & 158.00 & 1.76 & 0.51 & 2.23 & 49.86 \\
\hline Hydro complex $5 \mathrm{~g}$ & 130.46 & 1.42 & 0.41 & 2.05 & 46.52 \\
\hline Hydro complex $10 \mathrm{~g}$ & 155.24 & 1.84 & 0.57 & 2.27 & 51.61 \\
\hline Hydro complex 15 g & 168.18 & 2.16 & 0.59 & 2.46 & 57.72 \\
\hline L.S.D.(0.05) & 5.07 & 0.11 & 0.10 & 0.15 & 7.16 \\
\hline Treatments & & \multicolumn{4}{|c|}{$2^{\text {nd }}$ season (2009) } \\
\hline Control & 92.61 & 0.92 & 0.26 & 1.80 & 33.10 \\
\hline PG-Mix $5 \mathrm{~g}$ & 137.85 & 1.07 & 0.36 & 1.97 & 36.39 \\
\hline PG-Mix $10 \mathrm{~g}$ & 147.15 & 1.44 & 0.44 & 2.14 & 44.80 \\
\hline PG-Mix $15 \mathrm{~g}$ & 162.45 & 1.79 & 0.50 & 2.22 & 49.79 \\
\hline Hydro complex 5 g & 136.80 & 1.40 & 0.40 & 2.02 & 47.50 \\
\hline Hydro complex $10 \mathrm{~g}$ & 160.20 & 1.82 & 0.58 & 2.28 & 52.22 \\
\hline Hydro complex 15 g & 171.50 & 2.16 & 0.58 & 2.44 & 58.00 \\
\hline L.S.D.(0.05) & 8.42 & 0.16 & 0.09 & 0.19 & 5.17 \\
\hline
\end{tabular}

L.S.D. ${ }_{(0.05)}=$ Least significant difference at 0.05 level of probability.

\section{4- Stem length and Stem diameter $(\mathrm{cm})$ :}

The data in Table (5) show that all fertilizer treatment significantly increased stem length and diameter compared with the control. The highest recorded values of these parameters were obtained in plants received the highest level of HC (15 g). Also, the results revealed that applying the highest level of application of the two fertilizers used resulted in similar effects. It was found that applying any level of application of HC had significant similar effects on the above mentioned parameters.

\section{5- Stem dry weight (g):}

Applying all fertilizer treatments resulted in significant increase in stem dry weight compared with the control (Table 5). The highest significant values were obtained with plants received $15 \mathrm{~g} \mathrm{HC}$ followed by the treatment where the plants received $10 \mathrm{~g} \mathrm{HC}$.

\section{I- Root volume:}

Data in Table (5) demonstrate the significant effects of the fertilizer treatments on root volume compared with the control. The highest values or root volume were recorded in plants received $15 \mathrm{~g} \mathrm{HC}$. Also, it can be observed that applying either 15 or $10 \mathrm{~g}$ of $\mathrm{HC}$ fertilizer had significant similar effects on root volume. 
Table 4. Effect of different rates of application of two types of slow release fertilizers on leaf number per plant, leaf length $(\mathrm{cm})$, leaf width $(\mathrm{cm})$, leaf fresh weight $(\mathrm{g})$ and leaf dry weight (g) of Beaucarnea recuvata plants during 2008 and 2009 seasons

\begin{tabular}{|c|c|c|c|c|c|}
\hline Treatments & $\begin{array}{c}\text { Leaf } \\
\text { number / } \\
\text { plant }\end{array}$ & $\begin{array}{l}\text { Leaf length } \\
\text { (cm) }\end{array}$ & $\begin{array}{l}\text { Leaf width } \\
\quad(\mathrm{cm})\end{array}$ & $\begin{array}{c}\text { Leaf fresh } \\
\text { weight } \\
\text { (g) }\end{array}$ & $\begin{array}{c}\text { Leaf dry } \\
\text { weight } \\
\text { (g) }\end{array}$ \\
\hline & \multicolumn{5}{|c|}{$1^{\text {st }} \operatorname{season}(2008)$} \\
\hline Control & 19.66 & 34.73 & 0.46 & 17.72 & 3.52 \\
\hline PG-Mix $5 \mathrm{~g}$ & 27.66 & 42.36 & 0.66 & 27.06 & 5.26 \\
\hline PG-Mix $10 \mathrm{~g}$ & 40.33 & 54.16 & 0.70 & 36.63 & 6.24 \\
\hline PG-Mix $15 \mathrm{~g}$ & 44.00 & 55.40 & 0.68 & 39.60 & 8.33 \\
\hline Hydro complex $5 \mathrm{~g}$ & 42.66 & 40.33 & 0.71 & 49.76 & 12.33 \\
\hline Hydro complex $10 \mathrm{~g}$ & 45.66 & 52.93 & 0.73 & 50.46 & 13.26 \\
\hline Hydro complex $15 \mathrm{~g}$ & 48.00 & 66.20 & 0.96 & 60.60 & 16.20 \\
\hline L.S.D. ${ }_{(\mathbf{( 0 . 0 5 )}}$ & 8.39 & 3.60 & 0.14 & 7.10 & 0.76 \\
\hline Treatments & \multicolumn{5}{|c|}{$2^{\frac{\text { nd }}{2}}$ season $(2009)$} \\
\hline Control & 19.00 & 33.93 & 0.43 & 17.49 & 3.63 \\
\hline PG-Mix $5 \mathrm{~g}$ & 28.33 & 45.73 & 0.73 & 27.63 & 5.38 \\
\hline PG-Mix 10g & 39.66 & 55.36 & 0.80 & 39.00 & 6.34 \\
\hline PG-Mix $15 \mathrm{~g}$ & 42.66 & 57.13 & 0.76 & 41.23 & 8.44 \\
\hline Hydro complex $5 \mathrm{~g}$ & 41.66 & 44.06 & 0.74 & 51.23 & 12.66 \\
\hline Hydro complex $10 \mathrm{~g}$ & 43.66 & 52.00 & 0.80 & 52.53 & 13.60 \\
\hline Hydro complex $15 \mathrm{~g}$ & 49.00 & 65.43 & 0.97 & 63.60 & 16.40 \\
\hline L.S.D. .(0.05) & 6.40 & 3.65 & 0.13 & 8.78 & 1.00 \\
\hline
\end{tabular}

L.S.D. ${ }_{(0.05)}=$ Least significant difference at 0.05 level of probability.

\section{III- Chemical composition of leaves:}

\section{1-Total leaf chlorophyll contents:}

As shown in Table (6), total chlorophyll contents were significantly increased with all fertilizer treatments. The highest values were recorded in plants received the highest rate of application of PG (15 g) followed by the treatment where the plants received $10 \mathrm{~g}$ PG. Also, it was found that fertilizing the plants with the medium rate of application $(10 \mathrm{~g})$ of either $\mathrm{HC}$ or PG had significant similar effects.

\section{2- N, $P$ and $K$ contents of leaves:}

Results of the Beaucarnea leaves chemical analysis for their N, P and K contents (\%) are listed in Table (6). The results revealed that all fertilizer treatments significantly affected leaf N, P and K contents compared with the control in both seasons except for the treatment where the plants received the lowest rate of application of PG (5 g) which did not affect leaf K content for both seasons.

The plants received the highest rate of application of $\mathrm{HC}(15 \mathrm{~g})$ recorded the highest leaf $\mathrm{N}, \mathrm{P}$ and $\mathrm{K}$ contents. The results revealed that applying either the highest or the medium level of application of $\mathrm{HC}$ resulted in similar effects on leaf nitrogen and potassium contents for both seasons.

\section{3- Total carbohydrates of leaves:}

The data illustrated in Table (6) show that all fertilizer treatments had significant effects on leaf total carbohydrates compared with the control in both seasons 
Table 5. Effect of different rates of application of two types of slow release fertilizers on stem length $(\mathrm{cm})$, stem diameter $(\mathrm{cm})$, stem dry weight $(\mathrm{g})$ and root volume $\left(\mathrm{cm}^{3}\right)$ of Beaucarnea recuvata plants during 2008 and 2009 seasons

\begin{tabular}{|c|c|c|c|c|}
\hline Treatments & $\begin{array}{l}\text { Stem length } \\
\quad(\mathrm{cm})\end{array}$ & $\begin{array}{l}\text { Stem diameter } \\
(\mathrm{cm})\end{array}$ & $\begin{array}{l}\text { Stem dry } \\
\text { weight } \\
\text { (g) }\end{array}$ & $\begin{array}{l}\text { Root volume } \\
\left(\mathrm{cm}^{3}\right)\end{array}$ \\
\hline & \multicolumn{4}{|c|}{$1^{\text {st }}$ season $(2008)$} \\
\hline Control & 6.66 & 2.66 & 9.93 & 23.33 \\
\hline PG-Mix $5 \mathrm{~g}$ & 11.50 & 3.56 & 16.10 & 40.00 \\
\hline PG-Mix $10 \mathrm{~g}$ & 14.00 & 4.10 & 35.36 & 4.33 \\
\hline PG-Mix $15 \mathrm{~g}$ & 14.33 & 4.23 & 30.36 & 41.866 \\
\hline Hydro complex $5 \mathrm{~g}$ & 15.50 & 4.73 & 33.23 & 60.00 \\
\hline Hydro complex $10 \mathrm{~g}$ & 16.00 & 4.53 & 37.16 & 83.33 \\
\hline Hydro complex $15 \mathrm{~g}$ & 15.66 & 4.66 & 40.63 & 95.00 \\
\hline L.S.D. ${ }_{(0.05)}$ & 2.00 & 0.73 & 1.03 & 13.58 \\
\hline Treatments & \multicolumn{4}{|c|}{$2^{\text {nd }}$ season $(2009)$} \\
\hline Control & 7.66 & 2.73 & 10.36 & 22.66 \\
\hline PG-Mix $5 \mathrm{~g}$ & 12.00 & 3.60 & 16.96 & 41.66 \\
\hline PG-Mix $10 \mathrm{~g}$ & 13.66 & 4.20 & 36.00 & 50.00 \\
\hline PG-Mix $15 \mathrm{~g}$ & 14.00 & 4.20 & 31.83 & 43.33 \\
\hline Hydro complex $5 \mathrm{~g}$ & 15.00 & 4.63 & 33.60 & 61.66 \\
\hline Hydro complex $10 \mathrm{~g}$ & 14.33 & 4.60 & 38.23 & 85.00 \\
\hline Hydro complex 15 g & 15.33 & 4.76 & 41.70 & 91.66 \\
\hline L.S.D.(0.05) & 3.22 & 0.66 & 1.44 & 15.94 \\
\hline
\end{tabular}

L.S.D. ${ }_{(0.05)}=$ Least significant difference at 0.05 level of probability.

except for the treatment where the plants fertilized by the lowest rate of application of PG (5 g) which did not affect this parameter.

The highest significant values were recorded in plants received the highest rate of application of HC (15 g) as compared with other levels within each fertilizer.

\section{Discussion:}

In this investigation, characteristics such as plant height, leaf number/plant, leaf length, leaf width, stem length, stem diameter, leaf fresh and dry weight and root parameters were significantly affected by application of the two types of slow release fertilizers (Hydro complex 14:16:18) and (PG-Mix 12:11:18). In general, application of the Hydro-complex slow release fertilizer was much better then the other fertilizer (PG-Mix) especially at rate of $15 \mathrm{~g} /$ plant was the most effective treatment on most of the studied parameters. In most cases, the above mentioned treatment promoted vegetative growth, and resulted in significant increase in the values recorded for the different growth parameters compared with the other rates in both fertilizers. Similar promotion of the vegetative growth as a result of NPK fertilization has been reported by Laiche (1991) on Rhododendron obtusum plants, AbouTaleb and Hassan (1995) on Dracaena marginata and Dracaena fragrans, Catanzaro et al., (1998) on Chrysanthemum morifolium plants Altland et al., (2002) on three bedding plants (Catharanthus roseus, Tagetes patula and Ageratum houstonianum) and 
Table 6. Effect of different rates of application of two types of slow release fertilizers on total chlorophyll contents $(\mathrm{mg} / 100 \mathrm{~g}$ fresh weight), leaf nitrogen $(\%)$, phosphorus $(\%)$, potassium (\%) contents and total carbohydrates $(\%)$ of Beaucarnea recuvata plants during 2008 and 2009 seasons

\begin{tabular}{|c|c|c|c|c|c|}
\hline Treatments & $\begin{array}{c}\text { Total } \\
\text { chlorophyll } \\
\text { contents } \\
\text { mg/100 g leaf } \\
\text { fresh weight }\end{array}$ & $\mathbf{N}(\%)$ & $\mathbf{P}(\%)$ & $\mathbf{K}(\%)$ & $\begin{array}{c}\text { Total } \\
\text { carbohydrates } \\
(\%)\end{array}$ \\
\hline & \multicolumn{5}{|c|}{$1^{\text {st }}$ season $(2008)$} \\
\hline Control & 40.93 & 0.96 & 0.32 & 1.75 & 28.80 \\
\hline $\begin{array}{ll}\text { PG-Mix } 5 \mathrm{~g}\end{array}$ & 48.28 & 1.33 & 0.39 & 1.89 & 30.00 \\
\hline PG-Mix $10 \mathrm{~g}$ & 57.56 & 1.48 & 0.42 & 1.96 & 33.92 \\
\hline PG Mex $15 \mathrm{~g}$ & 65.24 & 1.59 & 0.48 & 2.06 & 39.89 \\
\hline Hydro complex $5 \mathrm{~g}$ & 47.36 & 1.47 & 0.43 & 1.89 & 37.11 \\
\hline Hydro complex $10 \mathrm{~g}$ & 54.40 & 1.62 & 0.48 & 1.98 & 42.31 \\
\hline Hydro complex $15 \mathrm{~g}$ & 55.98 & 1.73 & 0.59 & 2.13 & 49.00 \\
\hline L.S.D. $_{(0.05)}$ & 5.78 & 0.18 & 0.02 & 0.19 & 6.39 \\
\hline Treatments & \multicolumn{5}{|c|}{$2^{\frac{\text { nd }}{2}} \operatorname{season}(2009)$} \\
\hline Control & 41.21 & 0.98 & 0.34 & 1.76 & 27.19 \\
\hline PG Mex $5 \mathrm{~g}$ & 51.81 & 1.34 & 0.38 & 1.89 & 29.08 \\
\hline PG Mex $10 \mathrm{~g}$ & 57.21 & 1.49 & 0.41 & 1.97 & 33.72 \\
\hline PG Mex $15 \mathrm{~g}$ & 62.65 & 1.58 & 0.49 & 2.09 & 40.50 \\
\hline Hydro complex $5 \mathrm{~g}$ & 49.73 & 1.49 & 0.45 & 1.86 & 37.57 \\
\hline Hydro complex $10 \mathrm{~g}$ & 56.90 & 1.64 & 0.49 & 1.99 & 42.28 \\
\hline Hydro complex $15 \mathrm{~g}$ & 57.08 & 1.72 & 0.62 & 2.11 & 48.62 \\
\hline L.S.D. ${ }_{(0.05)}$ & 6.91 & 0.16 & 0.11 & 0.21 & 2.19 \\
\hline
\end{tabular}

L.S.D. ${ }_{(0.05)}=$ Least significant difference at 0.05 level of probability.

Fernandez-Escobar et al., on Olea europaea The favorable effect on the growth characteristics (compared the control ) can be explained by the important role of $\mathrm{N}, \mathrm{P}$ and $\mathrm{K}$ in the different physiological processes within the plant, which in turn affect the plant growth. Also, nitrogen is present in the structure of protein molecules, while phosphorus is an essential constituent of nucleic acid and phospholipids, and potassium is essential as an activator for enzymes involved in the synthesis of certain peptide bonds (Devlin, 1975).

Fertilizing the used indoor plants with the two types of slow release fertilizers has been found to increase the growth such as plant height, leaf number / plant and enhanced the growth of stem and roots. In this concern, Conover and Poole (1985) on Brassaia actinophylla and Ficus benjamina plants, Ticknor and Chaplin (1987) on Rhododendron obtusum and Klock-Moore (2001) on Impatiens wallerana and Salvia farinacea plants reported the beneficial effects of NPK on the growth. In this consideration, Marschner (1997) reported that using of NPK accelerated growth of plant by increasing the synthesis of protein and protoplasm.

The chemical analysis of fresh leaf samples has revealed that the total chlorophyll content was 
considerably affected by slow release fertilizers. In both seasons, unfertilized control plants had lower mean chlorophyll content than plants received the fertilizers. Increases in the total chlorophyll contents as a results of fertilization treatments have been recorded by Collard $e t$ al.,(1977) on Ficus benjamina. These results are reasonable since the nitrogen supplied by fertilization is essential in the structure of porphyrines, which are found in many metabolically active compounds including chlorophylls. Chlorophylls are bound to, and perhaps even embedded within protein molecules (Devlin, 1975). These findings agree with those of Schmiett and Schenk (1981) on Euphorbia pulcherrima, who reported that double application of NPK 20:5:10 increased the darkness of the leaves by $20 \%$. Also, Abou-Taleb and Hassan (1995) found that slow release fertilizers increased the total chlorophyll content in the leaves of Dracaena marginata and Dracaena fragrans plants .

The uptake utilization of N,P and K by Dracaena marginata and Beaucarnea recuvata plants were markedly affected by fertilization treatments. In both seasons, leaves of unfertilized plants had lower N,P and $\mathrm{K}$ contents than those of plants receiving slow release fertilizers treatments. The increase in the contents of nutrients was explained by Jain (1983), who stated that raising the levels of $\mathrm{N}, \mathrm{P}$ and $\mathrm{K}$ in the root medium leads to an increase in the absorption of these essential elements. These results are in agreement with the findings of Essa (1984) on rosa spp plants, Abou-Taleb and Hassan (1995 with Dracaena marginata and Dracaena fragrans plants and Clemens et al., (1998) on Zantedeschia aethiopica plants.

The effect of the slow release fertilizers on the total carbohydrates content was similar to the effect on the total chlorophyll contents. These results can be easily explained since, the nitrogen supplied by fertilization is essential in the structure of porphyrines and, consequently, lead to an increase in the contents of chlorophyll. Also, the porphyrine molecules are found in the cytochrome enzymes essential in photosynthesis. This increase in the content of chlorophyll and cytochrome enzymes resulted in an increase in the rate of photosynthesis, and a promotion in carbohydrates metabolism (Devlin, 1975). Similar increase in the carbohydrates content have been reported by El-Khateeb and Salem (1988) on Thuja orientalis, El-Naggar (1994) on Gladiolus hybrida and El-Fawakhry et al.,(2004) on Cyperus papyrus plants.

\section{REFERENCES}

Abou-Taleb, N.S. and S. M. Hassan (1995). Effect of commercial and slow release fertilizers on the growth and chemical composition of two Dracaena species. Annals of Agric. Sci. 40(2): 853-865.
Altland, J.E.; Gilliam,C.H.; J.H.Edwards; G.J.Keever; D.C.Fare and J. L. Sibley (2002).Fertilization and methods of application influence bedding plant growth and nitrogen leaching in urban landscapes.Journal of Enviromental Horticulture Vol.20 , No.4, pp. 204-213.

Basu, S.K.; K. Naveen and J.P. Srivastava (2010). Modeling NPK release from spherically coated fertilizer granules. Simulation Modelling Practice and Theory, 18(6): 820835.

Blaylock, A.D.; J. Kaufmann and R.D. Dowbenko (2005). Nitrogen fertilizer technologies. Western Nutrient Management Conf., Salt Lake City, UT. Vol.6, p. 8-13.

Bringham, F.T. (1982). Boron. In A. L. Page et. al., (ed) Methods of Soil Analysis, Part 2., Agronomy. 9:431:447.

Brown, J.O. and O. Lilleland (1946). Rapid determination of potassium and sodium in plant material and soil extracts by Flame photometry .proc. Armer. Soc.48:341-346.

Catanzaro, C.J.; K.A.Williams and R.J.Sauve (1998). Slow release versus soluble fertilization affects nutrient leaching of potted chrysanthemum. Journal of Plant Nutrition,21(5):1025-1036.

Chapman, H. D. and P. F. Pratt (1961). Methods of analysis for soils, plants and waters. Div. of Agric. Sci., Priced. Pub. 4034. Univ. of California, U.S.A.

Chien, S.H.; L.I. Prochnow and H. Cantarella (2009). Recent development of fertilizer production and use to improve nutrient efficiency and minimize environmental impacts. Advances in Agronomy, 102: 267-322.

Clemens,J.; D.J. Dennis; R.C. Butler; M.B. Thomas; A. Ingle and T.E. Welsh (1998). Mineral nutrition of Zantedeschia plants affectes plant survival, tuber yield, and flowering upon replanting. Jour. Hort. Sci. and Biotechnology, 73(6):755-762.

Collard,R.C.; J.N. Joiner; C. A. Conover and D.R. McConnel (1977).Influence of shade and fertilization on light compensation point of Ficus benjamina. J. Amer. Soc. Hort. Sci., 104 (4):447-449.

Conover, C.A. and R.T. Pool (1985). Comparison of a liquid fertilizer source with several slow release fertilizers on Brassaia actinophylla and Ficus benjamina. Foliage Digest ,8(6): 1-3.

Devlin, R.M. (1975). Plant Physiology. $3^{\text {rd }}$ Ed., Affiliated East-West Press Pvt.Ltd., New Delhi.

El-Fawakhry,F.M.; A. H. El-Naggar and A. A. M. El-Naggar (2004). Physiological studies on growth and flowering of Cyperus papyrus, L.2- Effect of mineral fertilization and light intensity. Alex J.Agric. Res., 49(3):107-119.

El-Khateeb, M.A. and M.A. Salem (1988). Effect of chemical fertilization on growth and chemical composition of Thuja orientalis L. seedlings. J. Agric. Res. Tanta Univ.,14 (2):925- 935.

El-Naggar, A.H.M. (1994). Effect of different ratios and levels of some fertilizer on the vegetative grwth, flowering and corms production of gladiolus. M.Sc. Thesis, Alex. Univ., Egypt. 
Essa, Z.M. (1984).Studies on the effect of foliar nutrition on some flowering ornamental plants. M.Sc. Thesis, Univ. of Ain Shams, Fac. Agric.,Cairo,A.R.E. pp.12-13.

Fernandez-Escobar, R. ; M. Benlloch; E. Herrera and J.M. Garcia-Novel (2009). Effect of traditional and slowrelease $\mathrm{N}$ fertilizers on growth of olive nursery plants and $\mathrm{N}$ losses by leaching. Scientia Hortriculturae, 101(1-2):3949.

Greig, J.; Motes; J. and A. Tikiriti (1968). Effect of nitrogen levels and micronutrients on yield, chlorophyll and mineral contents of spinach. Proc. Amer. Soc. Hort. Sci. $92: 508-515$.

Hartrath, H., (1986). Nitrogen should be release slowly. Gemuse, 22(8): 332-334.

Herbert, D.; Philipps, P.J. and R.E. Strange (1971). Determination of total carbohydrates . Methods in Microbiology. 5 B :204-244.

Hector G. A., D.B. Russell; A.V. Timothy; H.W. Edwin and P.A. Lawrence (2003). Effect of organic amendments and slow-release fertilizer on willow biomass production and soil chemical characteristics, Biomass and Bioenergy, 25 (4): 389-398.

Huxley, A. (1992). New RHS Dictionary of Gardening, 2:9697. Macmillan.

Irish, G. (2000). Agaves, Yuccas and Related plants: A gardeners Guide. Timber Press. p.187.

Jain,V.K. (1983). Fundamentals of Plant Physiology. S. Chand and Co., Ltd., Ram NAGAR, New Delhi.

Kirk, O. (1993). Encyclopedia of Chemical Technology. Controlled Release Technology, Vol. 7, Fourth Ed., John Wiley and Sons, Inc., p. 251-271.

Klock-moore, K.A. (2001). Effect of controlled-release fertilizer application rates on bedding plant growth in substrates containing compost. Compost Science \& Utilization, 9( 3):215-220.
Laiche,A.J. (1991). Evaluation of slow release fertilizers to produce container-grown landscape plants. Research Report-Mississippi Agricultural and Forestry Experiment Station, 16(7):3.

Lamont, G.P., G.C. Cresswell and L.J. Spohr (1988). Response on kentia palm (Howea forsterana) to controlled-release fertilizer, Scientia Horticulturae, 36 (34):293-302.

Marschner, H. (1997). Mineral Nutrition of Higher Plants. Second Ed, Academic Press INC. San Diego. P.889.

Oliet, J. ; R. Planelles; M. L. Segura; F. Artero and F. Jacobs.(2004).Mineral nutrition and growth of containerized Pinus halepensis seedlings under controlledrelease fertilizer. Scientia Horticulturae, 103(1):113-129.

Schmiett, K. and M. Schenk (1981). Poinsettia, Bark substrates instead of the usual soil. Herkommlicken Gb. 81 (35): 800-803. Hort.Abst., 1982, 52:3145.

Snedecor, G. and W. Cochran (1981). Statistical Methods. Seventh Ed., Iowa State Univ. Press Amer., Iowa, USA.

Ticknor, R.L. and M.H.Chaplin (1987).Effect of slow release fertilizer sources on flower formation and nutrien composition in Rhododendrons. Compined Proceeding of the International Plant Propagators Society,Vol. 28,pp 101-105.

Worrall, R.J.; G.P. Lamont; M.A. O'Connell and P.J. Nicholls (1987). The growth response of container-grown woody ornamentals to controlled-release fertilizers, Scientia Horticulturae, 32 (3-4): 275-286.

Xiang,Y.; J. Ji-yun; H. Ping and L. Ming-zao (2008). Recent advances on the technologies to increase fertilizer use efficiency. Agricultural Sciences in China, 7, (4): 469479.

Yuan-liang S.; W. Zhi-jie; C. Li-jun; Z. Xu-dong and M. Zong (2009). Development and application of slow release fertilizer, Agricultural Sciences in China, 8(6): 10 -12. 


\section{الملخص العربي}

\section{تأثير المعاملة بالاسمدة بطيئة التحلل على النمووالتركيب الكيماوى لبعض نباتات التنسيق الداخلى}

$$
\text { عاصم عباس النجار، على حسن النجار ونجلاء مُحمّة اسماعيل }
$$

وقـد أظهـرت نتـائج الدراسـة على نبـاتات القلة أن اضـافة سمـاد

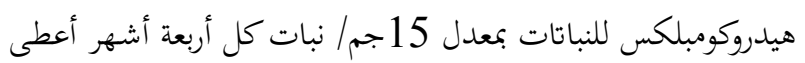

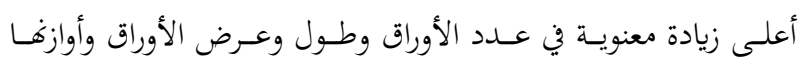

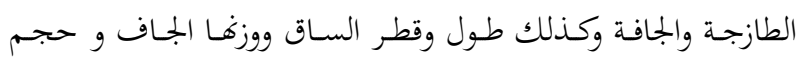

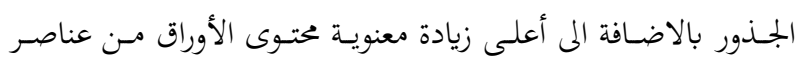
النتروجين و الفوسفور و البوتاسيوم وكذلك محتواها من الكربوهيدرات

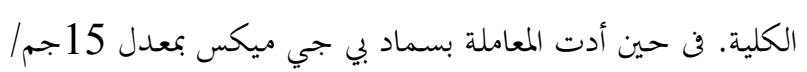

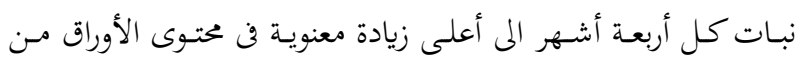

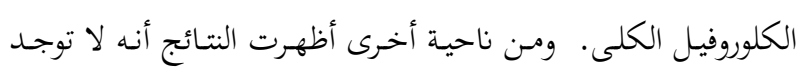

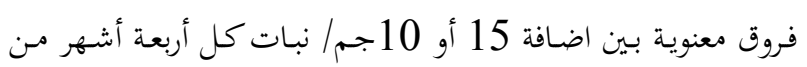

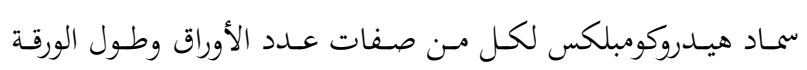

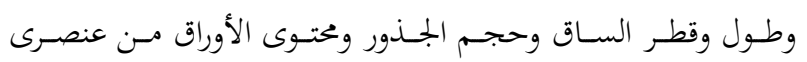

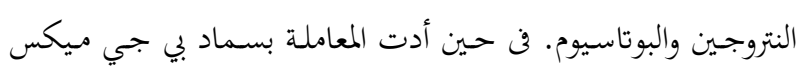

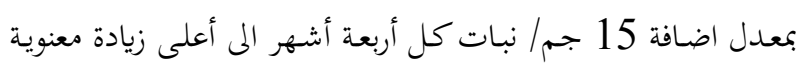
في محتوى الأوراق من الكلوروفيل الكلى. و توصى الدراسة باضافة السماد البطىء التحلل هيدروكومبلكس بمعدل10جم/ نبات كل أربعة أشهر للحصول على أعلى مواصفات

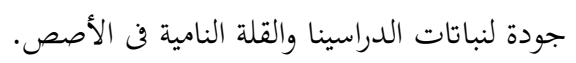

أجريـت هـذه الدراسـة في مسوسمي 2008 و 2009 في مشتلل جامعـة الاسكندرية لدراسـة تأثير نوعين مـن الأسمـدة المركبة البطيئة

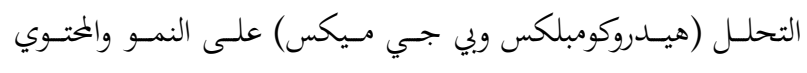

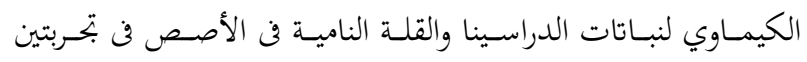

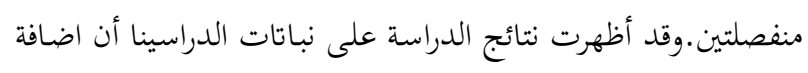

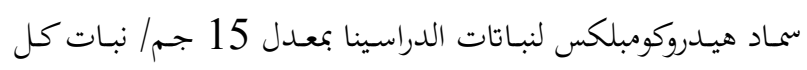

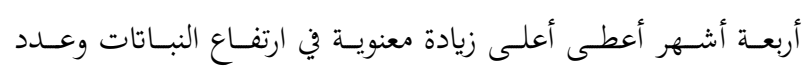

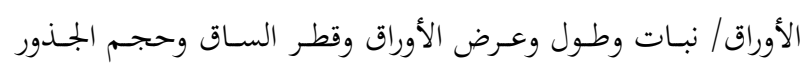

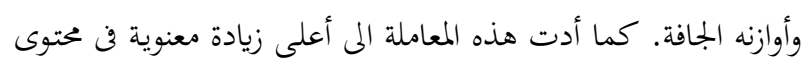

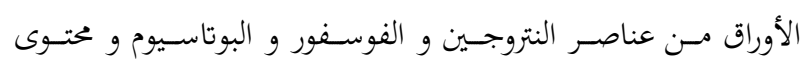

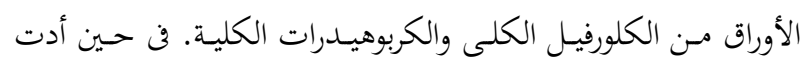

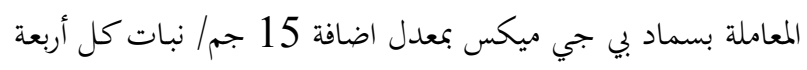

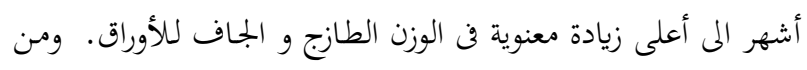

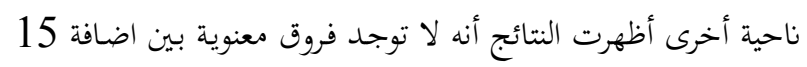

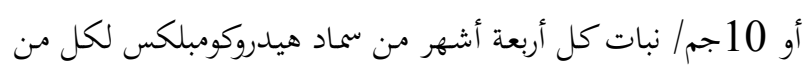

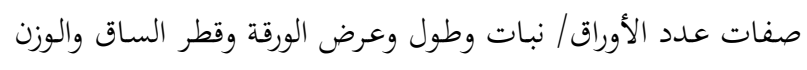

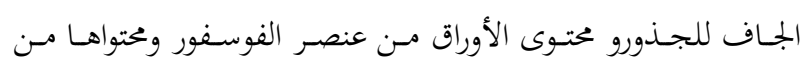

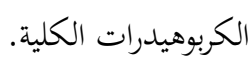

